\title{
地盤の変形を考慮したダム基礎岩盤の浸透流解析 \\ Groundwater analysis in dam basement of deformable \\ fractured rocks
}

$\begin{array}{llrr}\text { (侏熊谷組 (埼玉大学研究生) } & \text { 正員 } & \text { 伊藤 } & \text { 洋 } \\ \text { 埼玉大学工学部 } & \text { 正員 } & \text { 佐藤 } & \text { 邦明 } \\ \text { (侏) 熊 谷 組 } & \text { 正員 } & \text { 清水 } \text { 昭男 }\end{array}$

1. はじめに

岩盤浸透流の解析は，かつてダム基礎岩盤を対象になされることが多かったが，近年に招いては地下発電 所, 燃料地下備蓄, 放射性廃尧物空洞など新しくその利用範囲や重要性が増しつつある。しかしながら,ダ 厶基礎岩盤に扔ける浸透現象に括いても，いまだ未解明のいくつかの問題が残されている。たと兄ば，ダム 構築・湛水時に扔ける地山応力变化に起因する透水性への影響やそれと止水グラウト効果の関係, 扔よびダ ムの地震時挙動といったものである。こういった問題を究明するに当っては, 従来の均質場に扔ける二次元 流解析のみでは不十分であり，元来共存して挙動する岩盤地山と間隙水を一体化して取扱う必要がある。

本研究はこのような観点に立って, 割れ目系岩盤を多数の岩ブロックと弾性介在物を有する間隙系の集合 体としてモデル化し，地山応力と地下水運動を連成させて解析し得る理論を導びいて，ダム基礎岩盤の浸透 流解析をいくつか試み，透水特性に関していくつか新しい知見を得たのでここに報告する。

\section{2. 岩盤モデルとその定式化，および流れの基礎式}

岩盤地山は図ー 1 に示したように一般に岩質 (岩石) とその割れ目系により 構成されて扔り，元来二重空陌系と見れる。岩石はそれ自体の透水性は小さ く, 割れ目系は地山形成後の応力や風化によって後続作用により作られ，流 路系空隙として浸透流を支配することになる。同時に, 図中に招いて各岩石 の凹凸は互いに凸な部分で接触し, 場合によって風化物を含む。この接触点 は応力の変化に伴って変形し易く, 割れ目幅も動的に変化するものと考光ら

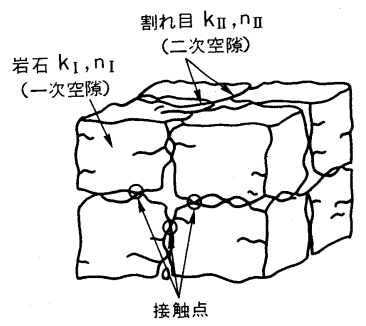

図-1 二重空隙岩盤モデル れる。図-2の岩ブロックモデルは,このような性質をむつ岩 盤地山の割れ目系の流れに焦点を当て, 岩石部は不透水性弾 性立方体ブロック集合によって, また, 各々の岩石は弾性介 在柱をはさみ割れ目系を形成すると見なしてモデル化したも のである。このような岩ブロックモデルによって岩盤地山の 透水性がどのように表されるか，その定式化を行う。

まず, 透水係数 $\mathrm{k}_{\mathrm{r}}$ は平行間隙内の粘性流の式より

$$
\mathrm{k}_{\mathrm{r}}=2 / 3 \cdot \mathrm{g} / \nu \cdot \mathrm{d}^{3} / \mathrm{s}
$$

と表せる。ここに, $\mathrm{g}$ : 重力加速度, $\nu$ : 動粘性係数, $2 \mathrm{~d}$

: 割れ目間隙幅, $\mathrm{s}$ : 割れ目の分布間隔である。

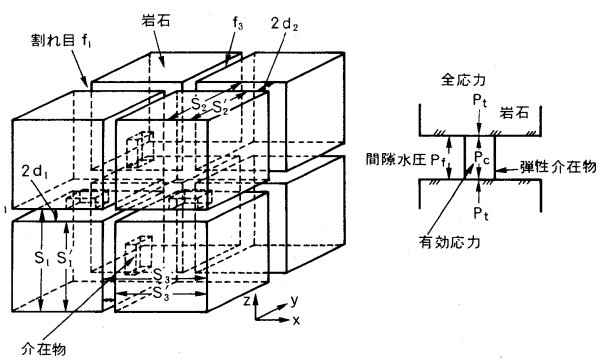

図-2＼cjkstart岩ブロックモデル つぎに，同図中左側に示したようにある深度に持ける岩盤地 山の全応力を $\mathrm{P}_{\mathrm{ti}}$, 有効応力 $\mathrm{P}_{\mathrm{ci}}$, 間隙水圧 $\mathrm{P}_{\mathrm{f}}$ とすると, これらの関係式は次のように書ける。

$$
\mathrm{P}_{\mathrm{ti}}=\mathrm{P}_{\mathrm{ci}}+\mathrm{P}_{\mathrm{f}}, \Delta \mathrm{P}_{\mathrm{ti}}=\Delta \mathrm{P}_{\mathrm{ci}}+\Delta \mathrm{P}_{\mathrm{f}}, \quad \mathrm{i}=1,2,3
$$

ここに, $\mathrm{i}:$ 割れ目の方向成分, $\Delta$ : 微小変化量, である。

また, 図ー2 に示した任意割れ目の分布間隔 $\mathrm{s}_{\mathrm{i}}$, 括よび割れ目幅 $2 \mathrm{~d}_{\mathrm{i}}$ の関係は次のように表せる。 $\mathrm{s}_{\mathrm{i}}=\mathrm{s}_{\mathrm{i}}^{\prime}+2 \mathrm{~d}_{\mathrm{i}}, \Delta \mathrm{s}_{\mathrm{i}}=\Delta \mathrm{s}_{\mathrm{i}}^{\prime}+\Delta 2 \mathrm{~d}_{\mathrm{i}}, 2 \mathrm{~d}_{\mathrm{i}}=2 \mathrm{~d}_{\mathrm{oi}}+\Delta 2 \mathrm{~d}_{\mathrm{i}}, \quad \mathrm{s}_{\mathrm{i}}=\mathrm{s}_{\mathrm{oi}}+\Delta \mathrm{s}_{\mathrm{i}}$ 
ここに， $\mathrm{s}_{\mathbf{i}}^{\prime}$ : ブロックの切長，であり，添字 0 は付加応力変化のない時（基準状態）の諸値を意味する。 さらに，上述のように割れ目間隙内の介在物を近似的に弾性角柱であるとすると， $\Delta 2 \mathrm{~d}_{\mathrm{i}}$ は次のようになる。

$$
\Delta 2 \mathrm{~d}_{\mathrm{i}}=-2 \mathrm{~d}_{\mathrm{oi}} / \mathrm{a}_{\mathrm{i}} \cdot \mathrm{E}_{\mathrm{c}} \cdot \Delta \mathrm{P}_{\mathrm{ci}}+2 \mathrm{~d}_{\mathrm{oi}} \cdot \mathrm{M}_{\mathrm{c}} / \mathrm{E}_{\mathrm{c}} \cdot \Delta \mathrm{P}_{\mathrm{f}}
$$

ここで, $\mathrm{a}_{\mathrm{i}}$ : 介在物の断面積が割れ目の面皘に占める割合 $\left(\mathrm{a}_{\mathrm{i}}<<1\right), \mathrm{E}_{\mathrm{c}}$ :介在物の弾性係数, $\mathrm{Mc}$ : 介在 物のポアソン比である。

同様に, ブロックの辺長 $\mathrm{s}_{\mathrm{i}}^{\prime}$ の変化量 $\Delta \mathrm{s}_{\mathrm{i}}^{\prime}$ は,

$$
\Delta \mathrm{S}_{\mathrm{i}}^{\prime} / \mathrm{s}_{\mathrm{oi}}^{\prime}=-1 / \mathrm{E}_{\mathrm{r}}\left(\Delta \mathrm{P}_{\mathrm{ti}}-\mathrm{M}_{\mathrm{r}} \Delta \mathrm{P}_{\mathrm{tj}}-\mathrm{M}_{\mathrm{r}} \Delta \mathrm{P}_{\mathrm{tk}}\right)
$$

となる。ここで, $\mathrm{E}_{\mathrm{r}}$ ：岩ブロック部の弾性係数, $\mathrm{M}_{\mathrm{r}}$ ：岩ブロック部のポアソン比である。

従って，式(1)〜 (5) より $\Delta \mathrm{P}_{\mathrm{ci}}$ を消去し， $\mathrm{a}_{\mathrm{i}} \mathrm{M}_{\mathrm{c}} \ll<1$ であるとすると，全応力扔よび間隙水圧の変化を考慮 した岩盤の透水係数が次のように求まる。

$$
\begin{aligned}
& \mathrm{k}_{\mathrm{i}}=\mathrm{k}_{\mathrm{oi}} \frac{\left\{1+1 / \mathrm{a}_{\mathrm{i}} \mathrm{e}_{\mathrm{c}}\left(\Delta \mathrm{P}_{\mathrm{f}} / \mathrm{E}_{\mathrm{r}}-\Delta \mathrm{P}_{\mathrm{ti}} / \mathrm{E}_{\mathrm{r}}\right)\right\}^{3}}{1+\mathrm{s}_{\mathrm{oi}}^{\prime} / \mathrm{s}_{\mathrm{oi}}\left\{\lambda_{\mathrm{i}} \Delta \mathrm{P}_{\mathrm{f}} / \mathrm{E}_{\mathrm{r}}-\left(1+\lambda_{\mathrm{i}}\right) \Delta \mathrm{P}_{\mathrm{ti}} / \mathrm{E}_{\mathrm{r}}+\mathrm{M}_{\mathrm{r}} \Delta \mathrm{P}_{\mathrm{ti}} / \mathrm{E}_{\mathrm{r}}+\mathrm{M}_{\mathrm{r}} \Delta \mathrm{P}_{\mathrm{tk}} / \mathrm{E}_{\mathrm{r}}\right\}} \\
& \mathrm{k}_{\mathrm{oi}}=2 / 3 \cdot \mathrm{g} / \nu \cdot \mathrm{d}_{\mathrm{oi}}^{3} / \mathrm{s}_{\mathrm{oi}}, \lambda_{\mathrm{i}}=1 / \mathrm{a}_{\mathrm{i}} \mathrm{e}_{\mathrm{c}} \cdot 2 \mathrm{~d}_{\mathrm{oi}} / \mathrm{s}_{\mathrm{oi}}^{\prime}, \quad \mathrm{e}_{\mathrm{c}}=\mathrm{E}_{\mathrm{c}} / \mathrm{Er}_{\mathrm{r}} \\
& \mathrm{k}_{\mathrm{x}}=\mathrm{k}_{1}+\mathrm{k}_{2}, \mathrm{k}_{\mathrm{y}}=\mathrm{k}_{1}+\mathrm{k}_{3}, \quad \mathrm{k}_{\mathrm{z}}=\mathrm{k}_{2}+\mathrm{k}_{3}(\mathrm{i}, \mathrm{j}, \mathrm{k}=1,2, \quad 3, \quad \mathrm{i} \neq \mathrm{j} \neq \mathrm{k})
\end{aligned}
$$

つぎに，流れの基礎式は微小直六面体のコントロールボリューム $\Delta \mathrm{V}=\Delta \mathrm{x} \Delta \mathrm{y} \Delta \mathrm{z}$ に扔ける流体質量の収支 から流れの連続方程式が次のように書ける。

$$
-\left\{\frac{\partial}{\partial \mathrm{x}}\left(\rho \mathrm{q}_{\mathrm{x}}\right)+\frac{\partial}{\partial \mathrm{y}}\left(\rho \mathrm{q}_{\mathrm{y}}\right)+\frac{\partial}{\partial \mathrm{z}}\left(\rho \mathrm{q}_{\mathrm{z}}\right)\right\} \Delta \mathrm{x} \Delta \mathrm{y} \Delta \mathrm{z}=\frac{\partial}{\partial \mathrm{t}}(\rho \mathrm{n} \Delta \mathrm{x} \Delta \mathrm{y} \Delta \mathrm{z})
$$

ここに, $\rho:$ 水の密度, $\mathrm{q}_{\mathrm{x}}, \mathrm{q}_{\mathrm{y}}, \mathrm{q}_{\mathrm{z}}: \mathrm{x}, \mathrm{y}, \mathrm{z}$ 方向流速, $\mathrm{n}:$ 空隙率, $\mathrm{t}:$ 時間である。 式(7)の右辺各項は水頭で書き, 式(2)〜(5)扣よびダルン一の式に基づいて整理すれば, 流れの基礎式は最終的 に次のようになる。

$$
\frac{\partial}{\partial \mathrm{x}}\left(\mathrm{k}_{\mathrm{x}} \frac{\partial \mathrm{h}}{\partial \mathrm{x}}\right)+\frac{\partial}{\partial \mathrm{y}}\left(\mathrm{k}_{\mathrm{y}} \frac{\partial \mathrm{h}}{\partial \mathrm{y}}\right)+\frac{\partial}{\partial \mathrm{z}}\left(\mathrm{k}_{\mathrm{z}} \frac{\partial \mathrm{h}}{\partial \mathrm{z}}\right)=\mathrm{S}_{\mathrm{f}} \frac{\partial \mathrm{h}}{\partial \mathrm{t}}-\mathrm{S}_{\mathrm{ta}} \frac{\partial \mathrm{h}_{\mathrm{ti}}}{\partial \mathrm{t}}-\mathrm{S}_{\mathrm{tb}} \frac{\partial \mathrm{h}_{\mathrm{tj}}}{\partial \mathrm{t}}-\mathrm{S}_{\mathrm{tc}} \frac{\partial \mathrm{h}_{\mathrm{tk}}}{\partial \mathrm{t}}
$$

$$
\text { ここに, }
$$

$$
\begin{aligned}
& \mathrm{S}_{\mathrm{f}}=\left\{\mathrm{n} / \mathrm{e}_{\mathrm{w}}+\sum_{\mathrm{i}=1}^{3} \lambda_{\mathrm{i}}\left(\mathrm{s}_{\mathrm{oi}}^{\prime} / \mathrm{s}_{\mathrm{oi}}\right)\left(1+\mathrm{n} \zeta_{\mathrm{ia}} \cdot \mathrm{s}_{\mathrm{oi}}^{\prime} / \mathrm{s}_{\mathrm{oi}}\right)\right\} \gamma_{\mathrm{w}} / \mathrm{E}_{\mathrm{r}}, \\
& \mathrm{S}_{\mathrm{ta}}=\left\{\sum_{\mathrm{i}=1}^{3}\left(\mathrm{~s}_{\mathrm{oi}}^{\prime} / \mathrm{s}_{\mathrm{oi}}\right)\left(\lambda_{\mathrm{i}} \mathrm{s}_{\mathrm{oi}}^{\prime} / \mathrm{s}_{\mathrm{oi}} \cdot \zeta_{\mathrm{ib}}+\mathrm{n}+\mathrm{n} \lambda_{\mathrm{i}}\right\} \gamma_{\mathrm{w}} / \mathrm{E}_{\mathrm{r}}\right. \text {, } \\
& \mathrm{S}_{\mathrm{tb}}=\mathrm{S}_{\mathrm{tc}}=\left\{\sum_{\mathrm{i}=1}^{3}\left(\mathrm{~s}_{\mathrm{oi}}^{\prime} / \mathrm{s}_{\mathrm{oi}}\right)\left(\lambda_{\mathrm{i}} \mathrm{s}_{\mathrm{oi}}^{\prime} / \mathrm{s}_{\mathrm{oi}} \zeta_{\mathrm{ic}}-\mathrm{nM}_{\mathrm{r}}\right)\right\} \gamma_{\mathrm{w}} / \mathrm{E}_{\mathrm{r}}, \mathrm{e}_{\mathrm{w}}=\mathrm{E}_{\mathrm{w}} / \mathrm{E}_{\mathrm{r}}, \\
& \zeta_{\mathrm{ia}}=\left(\mathrm{s}_{\mathrm{oi}}^{\prime} / \mathrm{s}_{\mathrm{oi}}-\mathrm{a}_{\mathrm{i}} \mathrm{e}_{\mathrm{c}} \lambda_{\mathrm{i}}-\gamma_{\mathrm{w}} / \mathrm{E}_{\mathrm{r}} \Delta \mathrm{h}_{\mathrm{ti}}+\mathrm{M}_{\mathrm{r}} \gamma_{\mathrm{w}} / \mathrm{E}_{\mathrm{r}} \cdot \Delta \mathrm{h}_{\mathrm{tj}}+\mathrm{M}_{\mathrm{r}} \gamma_{\mathrm{w}} / \mathrm{E}_{\mathrm{r}} \cdot \Delta \mathrm{h}_{\mathrm{tk}}\right) / \eta \\
& \zeta_{\mathrm{ib}}=\left\{\mathrm{s}_{\mathrm{oi}}^{\prime} / \mathrm{s}_{\mathrm{oi}}-\mathrm{a}_{\mathrm{i}} \mathrm{e}_{\mathrm{c}}\left(1+\lambda_{\mathrm{i}}\right)-\gamma_{\mathrm{w}} / \mathrm{E}_{\mathrm{r}} \cdot \Delta \mathrm{h}_{\mathrm{f}}+\mathrm{M}_{\mathrm{r}} \gamma_{\mathrm{w}} / \mathrm{E}_{\mathrm{r}} \cdot \Delta \mathrm{h}_{\mathrm{tj}}+\mathrm{M}_{\mathrm{r}} \gamma_{\mathrm{w}} / \mathrm{E}_{\mathrm{r}} \cdot \Delta \mathrm{h}_{\mathrm{tk}}\right\} / \eta \\
& \zeta_{\mathrm{ic}}=\mathrm{Mr}_{\mathrm{r}}\left(\mathrm{a}_{\mathrm{i}} \mathrm{e}_{\mathrm{c}}+\gamma_{\mathrm{w}} / \mathrm{E}_{\mathrm{r}} \cdot \Delta \mathrm{h}_{\mathrm{f}}-\gamma_{\mathrm{w}} / \mathrm{E}_{\mathrm{r}} \cdot \Delta \mathrm{h}_{\mathrm{ti}}\right) / \eta, \mathrm{n}=\sum_{\mathrm{i}=1}^{3} \mathrm{n}_{\mathrm{i}} \\
& \eta=\left[1+\mathrm{s}^{\prime}{ }_{\mathrm{oi}} / \mathrm{s}_{\mathrm{oi}}\left\{\lambda_{\mathrm{i}} \gamma_{\mathrm{w}} / \mathrm{E}_{\mathrm{r}} \cdot \Delta \mathrm{h}_{\mathrm{f}}-\left(1+\lambda_{\mathrm{i}}\right) \gamma_{\mathrm{w}} / \mathrm{E}_{\mathrm{r}} \Delta \mathrm{h}_{\mathrm{ti}}+\mathrm{M}_{\mathrm{r}} \gamma_{\mathrm{w}} / \mathrm{E}_{\mathrm{r}} \cdot \Delta \mathrm{h}_{\mathrm{ti}}+\mathrm{M}_{\mathrm{r}} \gamma_{\mathrm{w}} / \mathrm{E}_{\mathrm{r}} \cdot \Delta \mathrm{h}_{\mathrm{tk}}\right\}\right]^{2} \\
& \mathrm{n}_{\mathrm{i}}=2 \mathrm{~d}_{\mathrm{oi}} / \mathrm{s}_{o i} \cdot\left\{1+1 / \mathrm{a}_{\mathrm{i}} \mathrm{e}_{\mathrm{c}}\left(\Delta \mathrm{P}_{\mathrm{f}} / \mathrm{E}_{\mathrm{r}}-\Delta \mathrm{P}_{\mathrm{ti}} / \mathrm{E}_{\mathrm{r}}\right)\right\} /\left[1+\mathrm{s}_{o i}^{\prime} / \mathrm{s}_{o i}\left\{\lambda_{\mathrm{i}} \Delta \mathrm{P}_{\mathrm{f}} / \mathrm{E}_{\mathrm{r}}-\left(1+\lambda_{\mathrm{i}}\right) \Delta \mathrm{P}_{\mathrm{ti}} / \mathrm{E}_{\mathrm{r}}\right.\right. \\
& \left.\left.+\mathrm{M}_{\mathrm{r}} \Delta \mathrm{P}_{\mathrm{ti}} / \mathrm{E}_{\mathrm{r}}+\mathrm{M}_{\mathrm{r}} \Delta \mathrm{P}_{\mathrm{tk}} / \mathrm{E}_{\mathrm{r}}\right\}\right),(\mathrm{i}, \mathrm{j}, \mathrm{k}=1,2,3, \mathrm{i} \neq \mathrm{j} \neq \mathrm{k})
\end{aligned}
$$

$\gamma_{\mathrm{r}}$ : 岩ブロックの単位体積重量, $\mathrm{E}_{\mathrm{w}}$ : 水の体皘弾性係数, $\gamma_{\mathrm{w}}$ : 水の単位体皘重量, $\mathrm{h}_{\mathrm{f}}$ : 間隙水压 $\mathrm{P}_{\mathrm{f}}$ の水 頭值 $\left(h_{\mathrm{f}}=\mathrm{P}_{\mathrm{f}} / \rho \mathrm{g}\right), \mathrm{h}_{\mathrm{t}}$ : 全応力 $\mathrm{P}_{\mathrm{t}}$ の水頭換算值, $h$ : ピエゾ水頭 $\left(h=h_{\mathrm{f}}+z\right)$ である。

結局, 式(8)が岩ブロックモデルによる岩盤地山の流れの支配方程式となるが, 右辺の非定常項は各々の応 力成分 $\mathrm{P}_{\mathrm{f}}, \mathrm{P}_{\mathrm{ti}}, \mathrm{P}_{\mathrm{tj}}, \mathrm{P}_{\mathrm{tk}}$ によって変わることになる。

\section{3. 夕゙ム基礎岩盤浸透解析への適用}

2.で得られた理論をダム基礎岩盤の浸透流解析に適用し，タム建設後湛水による地山応力や間隙水圧の変 化に伴う透水係数変化が岩盤浸透流に及ほす影響について検討することとする。ここでは，コンクリートタ ムのような場合を想定し，ダム基礎岩盤には基本的にカーテングラウトを設けるものとするが，比較検討の 
ためそれを設けない場合，さらに岩盤地山を不変形等方均質地山と考えた流れについても解析を行う。

(1) 解析モデルと条件

解析モデルは，上述したコンクリートダムを考えて図ー3のよ うに設定する。このモデルは, 不透水性基盤上に無数の割れ目系 をむつ岩ブロック集合地山があってその上にダムを建設後湛水し たものである。また, ダム底の上流側には, 止水工としてのカー テングラウトを設けるあのとする。また, ダムは奥行方向 $(\mathrm{y}$ 方 向)には十分長く弾性理論に怙ける平面ひずみ状態にあるとする。

表ー 1 には解析条件を示してある。ダム寸法は, 底面幅 $\mathrm{B}=100$ $\mathrm{m}$, 高さ $\mathrm{H}_{\mathrm{o}}=100 \mathrm{~m}$ (湛水深に同じ), グラウト長さ $\ell=60 \mathrm{~m}$, 幅 $\mathrm{d}=5 \mathrm{~m}$, 地山厚さ $\mathrm{H}_{\mathrm{r}}=300 \mathrm{~m}$, 水平境界長さ $2 \mathrm{~L}=1000 \mathrm{~m}$ と する。また, 地山応力に係る物性は岩盤分類上 $\mathrm{C}$ 級程度の岩盤を 想定し, 岩石の弾性係数 $\mathrm{E}_{\mathrm{r}}=3.92 \mathrm{GN} / \mathrm{m}^{2}$, ポアソン 比 $\mathrm{M}_{\mathrm{r}}=0.3$, 単位体積重量 $r_{\mathrm{r}}=21.56 \mathrm{kN} / \mathrm{m}^{8}$, 水の単 位体積重量 $r_{\mathrm{w}}=9.8 \mathrm{kN} / \mathrm{m}^{3}$, 岩盤初期地山の側圧係数 $\mathrm{K}=1.0$ とする。一方, 岩盤の透水性に係る値とし ては, 基準状態の透水係数 $\mathrm{k}_{\mathrm{ox}}=\mathrm{k}_{\mathrm{oz}}=1.0 \times 10^{-5}$, $1.0 \times 10^{-6} \mathrm{~m} / \mathrm{s}$, ブロックの边長 $\mathrm{s}_{0}^{\prime}=0.1 \mathrm{~m}$ 介在物 に係る定数 $\mathrm{a} \mathrm{E}_{\mathrm{c}}=3.92,5.88 \mathrm{MN} / \mathrm{m}^{2}$, 間隙幅の $1 / 2$,

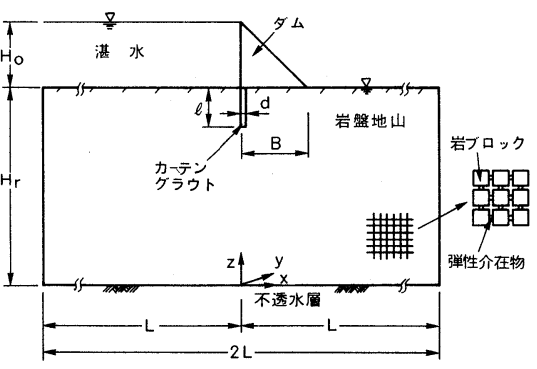

図一 3 解析モデル $\mathrm{d}_{\mathrm{o}}=1.97 \times 10^{-5}, 4.25 \times 10^{-5} \mathrm{~m}$, 空隙率 $\mathrm{n}_{\mathrm{o}}=$ $0.118,0.128 \%$, 水の動粘性係数 $\nu=1.0 \times 10^{-6} \mathrm{~m}^{2} / \mathrm{s}$ とする。また, 夕厶本体は十分透水係数は小さい と考光られるので, 不透水堤体と見なすが, 力学定数は $\mathrm{E}_{\mathrm{d}}=19.6 \mathrm{GN} / \mathrm{m}^{2}, \mathrm{M}_{\mathrm{d}}=0.2, \gamma_{\mathrm{d}}=22.54 \mathrm{kN} / \mathrm{m}^{8}$ ととる。他方, カーテングラウトのカ学定数は岩盤地山と同じとするが $\left(\mathrm{Eg}=3.92 \mathrm{GN} / \mathrm{m}^{2}, \mathrm{Mg}=0.3, \gamma \mathrm{g}\right.$ $\left.=21.56 \mathrm{kN} / \mathrm{m}^{8}\right)$, 透水性は $\mathrm{kg}=1.0 \times 10^{-7} \mathrm{~m} / \mathrm{s}$ （=グラウトの目標值 1 ルジオン $\left.{ }^{5}\right), \mathrm{ng}=0.1 \%$ に改良さ れたとする。解析は，地盤の変形を考虑し（以下恋形地山と称する）かつカーテングラウトの有る場合は Run - 1-1 Run - 3-1 と呼び，それの無い場合 Run $-1-2 \sim$ Run $-3-2$, 他方不変形等方均質地盤の場 合 (不変形地山) は各々 Run $-4-1$, Run $-4-2$ とする。

\section{(2) 解析方法と手順}

解析は基礎式(6)，(8)を用いた浸透流と応力を連成して計算することにな る。浸透流解析は Galerkin 有限要素法によって, 応力解析は等方性体に 拈ける Hookeの法則, 抢よび微小弾性変形理論に基づく線形弾性解析を同 じく有限要素法によって行う。この場合, ダム湛水後の流れの非定常性は弱 いこと, 式(8)を厳密に解くには地山応力の非定常変化を知る必要があること からここでは湛水後の定常流に限定して解析を行う。

図ー4は, その解析フローを示したものである, 解析手順は, 初期地山に 括ける透水係数分布を設定し，つぎにダム湛水後の応力分布上り新たな透水 係数分布を計算し，必要な境界条件下でピエゾ水頭分布を求める。解析はピ エゾ水頭分布と透水係数が同時に収束するまでくり返し計算によって行われ る。こうして透水係数分布, 打よびピエゾ水頭分布が決まると, 涌水量, 流 速べクトル分布を求めることができる。本モデルの解析に括いては, 要素形 状は四角形で要素数 253 , 節点数 288 とした。

(3) 解析結果と考察

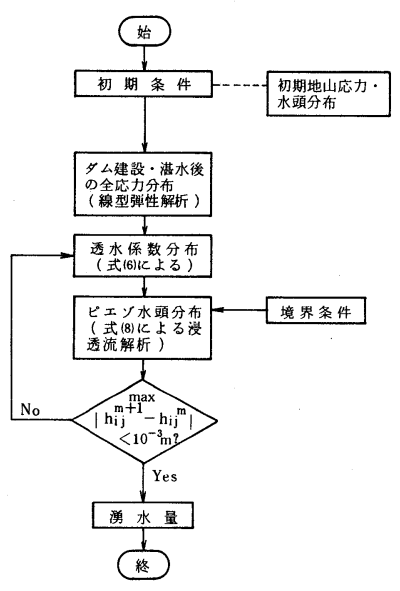

図-4 解析フロー 
表ー1に示した解析条件に従って全 8 ケースの解析 を行い, ダム基礎岩盤地山周辺の透水性の変化を吟味 する。

まず, 図一 5 は夕゙ム建設・湛水後の x ( $\mathrm{i}=3), \mathrm{z}$ $(\mathrm{i}=1)$ 方向成分全応力の分布を示したものである。 図中の実線の長さは応力值の大きさを示しているが, この場合には引張応力は生じない。応力は湛水側扣よ びダム底下で大きくなっている。

つぎに，図ー5で示した応力場扣よび図ー7 (後述) の水頭分布をもつ場合の岩盤地山透水係数分布に着目 しょう。図-6は, (a) Run-1-1, (b) $2-1,3-1$, (c) $2-2$, に扣ける透水係数 $\mathrm{k}_{\mathrm{x}}, \mathrm{k}_{\mathrm{z}}$ を基準状態（初期地 山の地表面に括ける值) のそれ $\mathrm{k}_{\mathrm{ox}}, \mathrm{k}_{\mathrm{oz}}$ で徐した比 で示したものである。(a), (b)はカーテングラウトの有 る場合で，(c)は無いそれである。まず， 3 者に共通し ていることは, 基本的に透水係数は深度が増すに伴。 て小さくなるが, 湛水側の地山表面付近では逆に基準 状態のそれに比べて大きくなっている。ダムょり下流 側遠方では地下水流の影響を受けにくいので初期地山 に怙ける透水係数分布と同じであり，側圧係数 $\mathrm{K}=1.0$ であるから $\mathrm{k}_{\mathrm{x}}$ と $\mathrm{k}_{\mathrm{z}}$ は等しくなっている。また, 湛水 側の地山では間隙水圧 (圧力水頭) の増大によって透 水係数は下流側に比べて大きくなり,さらに $\mathrm{k}_{\mathrm{z}}$ が $\mathrm{k}_{\mathrm{x}}$ より小さくなるといったことが同える。一方，カーテ ングラウトの有る場合の(a)，(b)の $\mathrm{k}_{\mathrm{x}}, \mathrm{k}_{\mathrm{z}}$ に目を転じ ると, それらはグラウト壁近傍の湛水側で急変し, い ずれも減少するといった傾向が見られる。さらに(a) Run-1-1 と(b) 2-1，3-1 を比較すると(b)の $\mathrm{k}_{\mathrm{x}} /$ $\mathrm{k}_{\mathrm{ox}}, \mathrm{k}_{\mathrm{z}} / \mathrm{k}_{\mathrm{oz}}$ の変化量が(a)のそれより大きくなってい ることが認められる。これは, 介在物に係る定数 $\mathrm{a}_{\mathrm{c}}$ が小さいために応力変化が大きくなることに起因する。

ここで，このような透水係数分布をもつ岩盤地山に

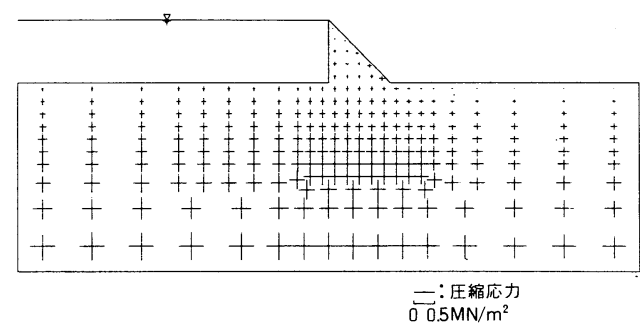

図-5 全応力 $\left(P_{t x}, P_{t z}\right)$ の分布

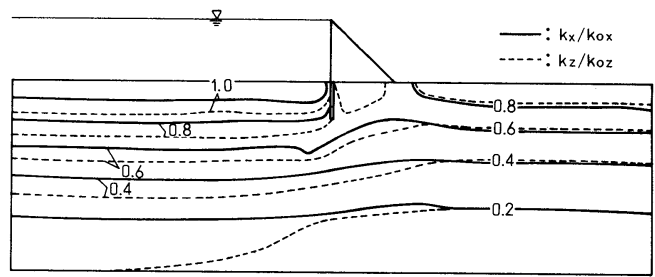

(a) Run - 1-1 の場合

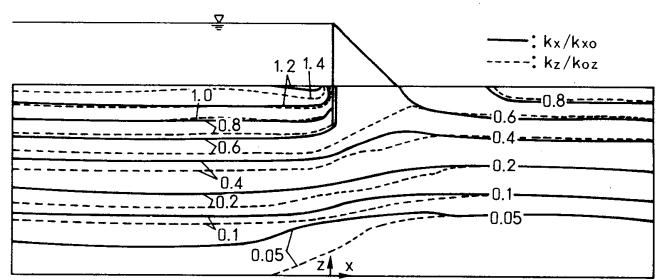

(b) Run -2-1, 打よびRun-3-1 の場合

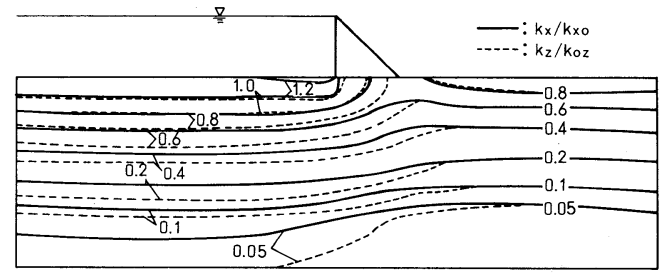

(c) Run $-2-2$ の場合

\section{図-6 無次元透水係数 $k_{x} / k_{o x}, k_{z} / k_{o z}$ の分布} 招ける無次元ピエゾ水頭分布がどうなるか, 変形地山の Run-1-1, 2-1 と不変形地山とした Run-4-1 の それらを(a)カーテングラウトの有る場合と(b)無い場合について示した図ー 7 について見てみよう。まず，(a) 図に括いてピエゾ水頭分布は, 変形地山で特に $\mathrm{a} \mathrm{E}_{\mathrm{c}}$ の小さいRun-2-1 の場合, 不変形地山の Run $-4-1$

（図中実線）と比べてその広がりは小さく，ダム底直下地山に集まるような形状を呈していることが分かる。 つまり，水頭はダム底直下地山を中心として急激に変化する。また，ダム底近傍の水頭分布は湛水側に進む ことも認められる。一方，グラウト壁の無い場合の(b)図に颃いてもグラウト壁周辺を除いて水頭分布は(a)の それと類似の形状・傾向を示している。

つぎに,図ー8は上述した透水係数括よび水頭分布での圧力水頭分布と流速べクトルをRun $-2-1$ とun -4 -1の場合について示したものである。流れはいずれもダム底を中心にグラウト壁を回り込むように湛水側から 


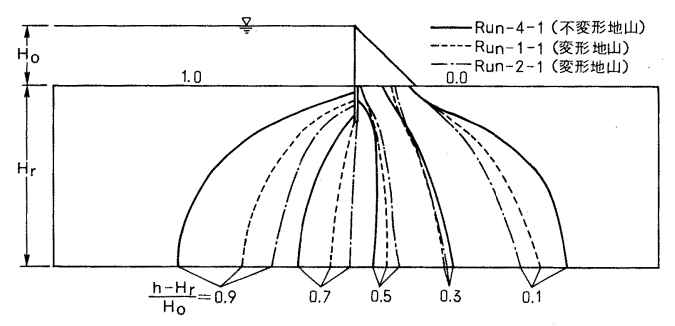

(a) カーテングラウトの有る場合

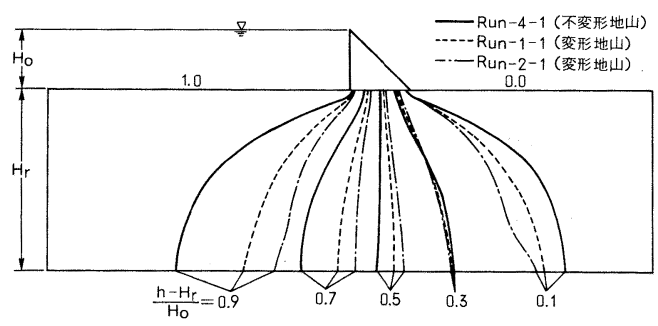

(b) カーテングラウトの無い場合

図-7 無次元ピエゾ水頭 $\left(h-H_{r}\right) / H_{0}$ の分布

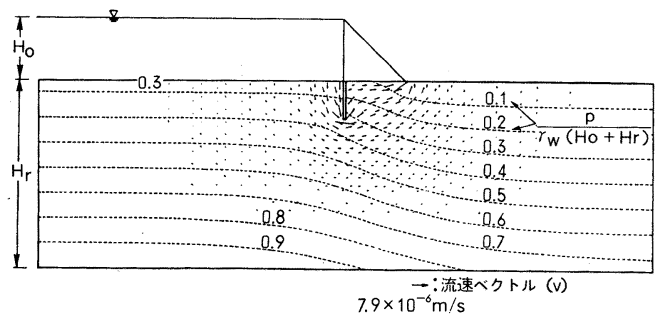

(a) Run $-2-1$ (変形地山)

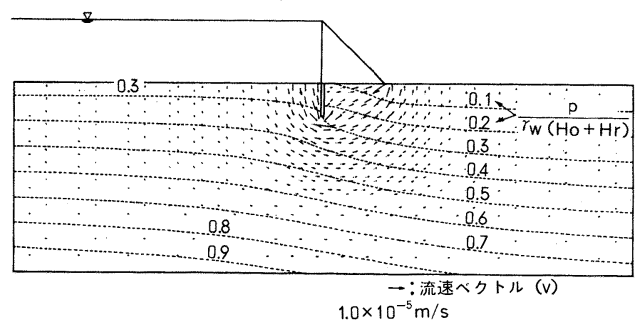

(b) Run -4-1（不変形地山）

㓙-8 流速ベクトル, および無次元圧力水頭 $\mathrm{p} / \gamma_{\mathrm{w}}\left(\mathrm{H}_{\mathrm{o}}+\mathrm{Hr}_{\mathrm{r}}\right)$ の分布

下流側へ向かうが, 両者を比較するとRun-2-1 の場合, つまり変形地山での流れの場は夕゙ム底下地山の比 較的狭い領域に限られていることが分かる。これは図ー7で示した水頭分布がダム底直下地山で急変し，かつ 全体的な深さ方向の透水係数の減少と湛水側地表面近くでのそれの増大等による結果であると考学得る。一 方, 圧力水頭を比較してみると, (a) Run-2-1の方が(b) Run-4-1に比べてダム底下地山でやや大きくなって 扣り, 変形地山では湛水によって一層間隙水圧が上昇する可能性を示唆しているものと思われる。

図ー 9 は,グラウト壁の有る場合の下流側地表面に括ける鉛直 上向き流速べクトル $\mathrm{v}$ をダム底の $\mathrm{A}$ 点に怙けるそれ $\mathrm{v}_{\mathrm{A}}$ との比で示 したものである。図中の実線は不変形地山の $\mathrm{v} / \mathrm{v}_{\mathrm{A}}$ 分布で Run -4 - 1 の場合である。 $\mathrm{v} / \mathrm{v}_{\mathrm{A}}$ (涌水量）はいずれもダムから離れるにつ れて急激に減少する。各々を比較してみると,ダム近くでは変形 地山の Run - 1-1，2-1の $\mathrm{v} / \mathrm{v}_{\mathrm{A}}$ が不変形地山の Run -4-1 のそれ に比べてやや大きくなるが, ダムよりある程度離れると逆にRun -1-1, 2-1 の方が小さくなっていることが判読できる。これ らの結果は図 -8 の流況からも同え十分納得できる。つぎに, 参 考のため下流側湧水量 $\mathrm{q}_{\mathrm{t}}$ と(1)カーテングラウトの有る場合と (2) 無い場合の湧水量比(1)/2)をとめたものが表 - 2 である。(1)/2)は

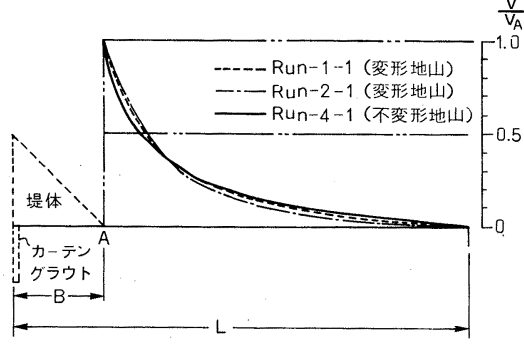

図ー9 カーテングラウトの有る場合の下 流側地表面における無次元鉊直上 向き流速 $v / v_{A}$ の分布 はグラウト壁による湧水量低減効果を表す。同表から単純に透水 係数が変化する変形地山とそれの変化しない不変形地山の $\mathrm{q}_{\mathrm{t}}$ ，あるいは(1)/(2)を比較することはできないが， いまRun-4-2 を基準にして湧水量が透水係数に比例するとして変形地山が不変形地山で代表されたときの 平均透水係数を求めると, 各々 Run-1-2で $\mathrm{k}_{\mathrm{x}}=\mathrm{k}_{\mathrm{z}}=6.6 \times 10^{-6} \mathrm{~m} / \mathrm{s}, \mathrm{Run}-2-2,5.3 \times 10^{-6} \mathrm{~m} / \mathrm{s}, \mathrm{Run}-$ $3-2,5.3 \times 10^{-7} \mathrm{~m} / \mathrm{s}$ となる。そこでこれらの透水係数を図ー6で示した透水係数分布と比べるといずれすグラ

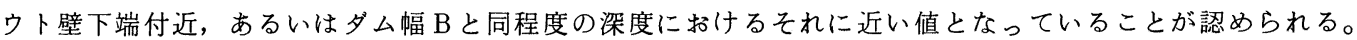


一方，この場合に怙けるグラウト壁の涌水低減効果(1)/2(2), $15 \sim 30 \%$ 程度であ る。また，表中 Run-4-2の〔 了内の值は従来の写像解より参考までに求めたも のであるが, 数值解析によるそれと比較的よく一致している。

つぎに，ダムの安定性に係るダム底に拈ける揚圧力 $\mathrm{P}_{\mathrm{v}}$ の無次元分布を示したも のが図ー10である。図中の(a)はカーテングラウトの有る場合で(b)はその無い場合を 示す。これより, (b)図から変形地山 Run - 1-2, 3-2 の $\mathrm{P}_{\mathrm{v}} / r_{\mathrm{w}} \mathrm{H}_{\mathrm{o}}$ が不変形地山 Run -4-2のそれをやや上回っていることが分かる。一方, (a)図の場合は, 揚圧力 $\mathrm{P}_{\mathrm{v}}$ が基本的にグラウト壁の透水係数と地山のそれの差に依存して変わり, 地山の透水 係数が小さくなってグラウト壁のそれに近づくと $\mathrm{P}_{\mathrm{v}}$ は大きくなるとい った性質をむつので，上述した表 -2 の場合と同様に透水係数の評価の 異なる両者を等価なものとして単純に比べることはできない。ただ，変 形地山の場合, 透水係数は深度方向に低下するので, 同時にグラウト壁 のそれとの差も小さくなり，グラウト壁による湧水括よび揚圧力低减効 果がそしくなってくることは確かであろう。

\section{4. むすひ}

本研究は, ダム基礎岩盤に抢いて地山の変形を考慮した場合の透水特 性の基本的性質について明らかにするため, 岩ブロックモデルを導入し て地山応力と浸透流の連成解析を行。て不変形地山のそれと比較・検討 したものである。その結果, ダム建設後の湛水によって地山透水係数は 特に湛水側地山とグラウト壁周辺で大きく変化し，湛水側地表付近では

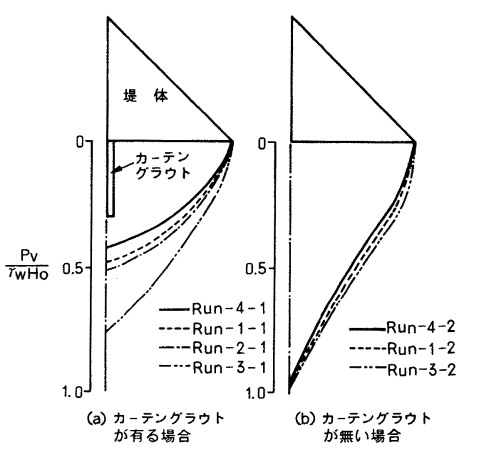

図-10 無次元揚圧力 $P v / \gamma_{w} H_{0}$ の分布 基準状態の透水係数より大きくなることが判明した。また，水頭も急激 に変化することとなって, 流れの場はダム底下の比較的狭い領域に限られ，そのため下流側湧水むダム近く で大きくなりそれより離れるに伴って急激に減少してくることも分かった。これらの結果は, ダム基礎岩盤 に係る諸問題を考孚る上で有用と思われる。最後に本計算を進めるに当って協力していただいた侏熊谷組 新井, 坂口, 西山の 3 氏, 扣よび資料を提供していただいた同技研の佐藤英明氏に扣礼申し上げる。

\section{参考文献}

1)大長昭雄：アーチダムの基盤内の浸透流に関する実験的研究，土木学会論文集，第 97 号，1963.9 2)宮田美幸：高瀬ダム基礎岩盤のグラウティングの検討（第一報），発電水力， No.149，1977.7

3) D.T. Snow : Hydrogeology of induced seismicity and tectonism: Case histories of Kariba and Koyna, The Geological Society of America, Special Paper 189, 1982

4)K. Sato et al. : Groundwater analysis of underground cavern by means of rock block model, Soils and Foundations, Vol. 22, №.4, 1982

5)建設省河川局開発課監修：グラウチング技術指針・同解説，（財）国土開発技術研究センター，1983.11

6) P. YA. Polubarinova-Kochina : Theory of Ground Water Movement, Translated from Russian by J.M. Roger De Wiest, Princeton Univ. Press., 1962 